\title{
Study on the Personnel Training Mode of School-Enterprise Cooperation in Higher Vocational College
}

\author{
Xianbing Ji, Yinxia Chen ${ }^{*}$ \\ Environment Management College of China, Qinhuangdao, Hebei, China \\ jixianbing1981@163.com, "chyxsd@163.com
}

\begin{abstract}
Personnel training mode of school-enterprise cooperation is an efficient way to reaching the training target in higher vocational college. The present situation and main problems of school-enterprise cooperation in our country was analyzed. Corresponding countermeasure and suggestion was put forward in order to promote the development of vocational education.
\end{abstract}

Keywords - higher vocational college, school-enterprise cooperation, status, study

\section{高职院校校企合作人才培养模式的研究}

\author{
纪献兵 陈银霞 \\ 中国环境管理干部学院, 秦皇岛, 河北, 中国
}

\begin{abstract}
摘 要 校企合作是推动和发展高职教育的有效途径。文章分析了目前我国高职院校校企合作的现状和存在的主要问题, 提出了 相应的对策和建议, 以期推动我国高职教育的发展。
\end{abstract}

关键词 高职院校, 校企合作, 现状, 研究

\section{1. 引言}

校企合作是推动和发展高职教育的有效途径。高等职 业教育的根本任务是以培养生产、建设、管理、服务第一 线的高端技能型专门人才。 2011 年 8 月教育部发布的《关 于推进高等职业教育改革创新引领职业教育科学发展的若 干意见》中明确提出高等职业教育必须坚持以服务为宗旨、 以就业为导向, 走产学研结合发展道路的办学方针。近年 来, 高职院校努力探索校企合作的机制和模式, 积极谋求 校外合作平台, 这为当地经济建设和有关行业培养了一批 急需的应用型人才, 但同时也不乏诸多问题和困惑。本文 分析了我国高职院校校企合作的现状和问题, 同时提出相 应的对策和建议, 为我国高职教育的校企合作发展提供有 益参考。

\section{2. 我国高职院校校企合作的现状}

随着职业教育的蓬勃发展, 很多高职院校已经在积极 开展校企合作的办学模式, 通过近年来的摸索实践, 已经 取得一定的成绩和宝贵经验。但就目前情况来看, 由于学
校的环境和专业设置, 企业和学校之间合作的有效性和主 动性等方面存在着差异, 校企合作的内容、形式和途径等 方面也参差不齐。

一般来说, 按照校企合作的培养模式来分, 我国高职 教育校企合作主要有以下几种 ${ }^{[1]}$ :

一、企业配合模式。企业配合模式的人才培养目标和 计划主要由学校提出和制定, 学生在学校完成理论学习, 是以学校为主体, 企业处于辅助地位进行的。企业根据学 校的要求提供实践场所, 如建立校外实训基地, 有时也由 企业投入设备和资金帮助学校建立校内实训基地, 设立奖 学金等, 从而实现生产车间与实习车间合一、学习与生产 合一, 使校企双方实现互利共赢。

二、“订单式”培养模式。“订单式” 培养模式实行 校企共同培养, 企业即参与研究和制定培养目标、教学计 划、教学内容和培养方式, 又参与培养学生的实践经验。 这种合作模式应用灵活, 学校和企业有着利益共同点, 企 业能够比较积极的参与到教育的各个环节。 
三、实体合作模式。这种模式对企业的合作热情与合 作条件要求很高, 目前我国高职教育采用这种合作模式的 较少。实体合作模式主要是企业以设备、场地、技术、师 资、资金等多种形式向高职院校注入股份、合作办学。企 业是更为整体、深层次的参与学校的管理, 企业与学校共 同培养学生成为企业的分内之事。

若按照校企合作的深度, 可以分为浅层次、中层次和 深层次三个方面 ${ }^{[2]}$ 。浅层次合作主要是指学校与企业签订 实习协议, 建立专家和实习指导委员会, 在企业建立实习 基地, 逐步形成产学合作。中层次合作是指学校根据企业 需求设置专业, 按岗位群的分类确定专业能力结构和非专 业能力素质的需求, 建立由学校和企业专家共同参加的专 业指导委员会, 学校组织专家和教授为企业提供咨询和培 训等服务, 为企业提供智力支撑, 企业参与教学计划的制 订、实施、检查和调整, 与学校共同完成教学任务。深层 次合作是指企业与学校紧密结合, 企业对高职院校承担决 策、计划、组织和协调等管理功能, 同时企业以场地、资 金、设备等形式向学校投资, 分享办学效益, 真正实现 “教 学一科研一开发” 三位一体; 学校针对企业的需求发展科 技攻关项目和研究方向, 并将科技成果转化为生产工艺、 产品和经营决策, 提高整体效益。目前我国高等职业教育 的校企合作的形式主要还停留在浅层次和中层次的起步阶 段, 其合作深度和广度距高层次阶段相差甚远。

\section{3. 校企合作存在的主要问题}

高职院校校企合作人才培养模式已被政府和高校所认 同, 在过去的几十年中取得了相当的进展, 学校与企业进 行了不同形式和不同层次的合作, 这为地方经济建设和有 关行业培养了一批急需的应用型人才, 但校企合作的深度 和广度有待进一步提高。主要有以下几方面的问题:

\section{1 缺乏完备的法律制度}

校企合作成功的很重要一点就是国家有比较完备的制 度体系, 有相应的机制监管, 但目前校企合作的法律制度 还很不健全且可操作性不够强; 此外, 没有监管机构对校 企合作的双方进行严格监管; 这都会使得校企合作双方在 不需要付出代价的情况下随意退出合作, 给对方造成损失。

\section{2 企业的积极性不高}

企业想通过校企合作提高员工素质或者在技术革新中 获取学校技术支撑, 但企业的这一目的较难达到。大多数 高职院校只把企业当成实习场所, 并不能满足企业的愿望。 主要原因可能是一些学校师资力量薄弱, 科研水平和技术 能力不强, 导致企业合作的兴趣不高, 双方无法建立长期
稳定的合作关系。

\section{3 职业资格制度不完善}

职业资格制度是保证校企合作深入开展的一项重要措 施。一些发达国家已形成一种学员无职业资格证书就找不 到工作、企业也不能录用的社会环境, 而我国职业资格制 度相差甚远, 企业用工、人员上岗有很大的随意性, 这导 致职工学习的积极性不高。

\section{4. 对策与建议}

\section{1 转变观念}

真正意义上的校企合作能使理论教学与实践教学紧密 结合。高等职业教育能否有生命力, 关键在于高等职业教 育能否办出特色, 校企合作是高职教育发展的根本出路, 这个观念必须树立起来。

\section{2 制定与校企合作相关的法律法规}

法律法规的完善是校企合作的保障。法律应对校企合 作双方的权利、义务和法律责任进行明确规定, 保护校企 合作双方的利益; 法律也应明确政府相关部门的责任及作 用, 同时政府应检查督促和搭建信息平台为校企合作有序 进行创造条件。

\section{3 调动企业的积极性}

提高企业的积极性, 从根本上来说就是学校采取措施, 切实让企业获得利益。高职院校主动让企业参与学校的专 业建设, 让企业的技术骨干参与到制定培养目标和课程方 案、建设实训基地、培养师资队伍、制定教学计划等专业 建设的各项工作中, 并对技术骨干给予一定的奖励措施; 聘请企业技术人员担任实习指导老师, 努力培养企业急需 的人才; 主动参与企业的项目研究与开发, 利用学校的资 源优势, 对企业员工进行岗前、转岗和进修培训, 实实在 在为企业办实事。

\section{4 完善职业资格制度}

目前一些高职院校在培养计划中, 虽然已明确学生应 掌握哪些相关的职业资格证书或技术等级证书, 并进行相 应的培训和考证, 但职业资格证书获取后的作用似乎不大, 这与我国职业资格制度不完善有莫大的关系。我国应尽快 制定相应的措施并严格执行, 尽快形成一种学员无职业资 格证书就找不到工作、企业也不能录用的社会环境。

\section{5. 结束语}

校企合作是职业教育必走的道路。但目前我国学校与 
企业合作办学的深度不够, 这可通过提高企业的积极性, 增强学校的师资力量, 同时制定法律法规和发挥政府的宏 观调控职能, 形成一种法律有规定、政府有措施、学校有 能力, 企业有动力的办学模式, 从而促进我国高职院校校 企合作的健康有序发展。

\section{6. 致谢}

本文为河北省高等教育学会基金一般项目《高等职业 院校校企合作人才培养模式研究》(GJXH2013-120)的阶段 性成果之一。

\section{参考文献(References)}

[1] H. J. Cui, Situation and countermeasure of school-enterprise cooperation in higher vocational college. Textile education, vol.24, pp. 25-27, 2009.

[2] W. X Zhang, Thinking and suggestion about the status of the school enterprise cooperation occupation. Education and vocation, vol.9, pp. 38-39, 2011. 